OPEN ACCESS

Edited by:

Eckhard Lammert, Heinrich Heine University of

Düsseldorf, Germany

Reviewed by: Mathieu Latreille, Medical Research Council, United Kingdom Barak Blum, University of Wisconsin-Madison, United States

${ }^{*}$ Correspondence: Limor Landsman

limorl@tauex.tau.ac.il

${ }^{\dagger}$ These authors have contributed equally to this work

Specialty section:

This article was submitted to Diabetes: Molecular Mechanisms, a section of the journal Frontiers in Endocrinology

Received: 12 February 2021 Accepted: 08 April 2021

Published: 26 April 2021

Citation: Burganova G, Bridges $C$, Thorn P and

Landsman L (2021) The Role of Vascular Cells in Pancreatic Beta-Cell Function.

Front. Endocrinol. 12:667170 doi: 10.3389/fendo.2021.667170

\section{The Role of Vascular Cells in Pancreatic Beta-Cell Function}

\author{
Guzel Burganova $^{1 \dagger}$, Claire Bridges ${ }^{2 \dagger}$, Peter Thorn $^{2}$ and Limor Landsman ${ }^{1 *}$ \\ ${ }^{1}$ Department of Cell and Development Biology, Sackler Faculty of Medicine, Tel Aviv University, Tel Aviv, Israel, ${ }^{2}$ Charles \\ Perkins Centre, Faculty of Medicine and Health, University of Sydney, Camperdown, NSW, Australia
}

Insulin-producing $\beta$-cells constitute the majority of the cells in the pancreatic islets. Dysfunction of these cells is a key factor in the loss of glucose regulation that characterizes type 2 diabetes. The regulation of many of the functions of $\beta$-cells relies on their close interaction with the intra-islet microvasculature, comprised of endothelial cells and pericytes. In addition to providing islet blood supply, cells of the islet vasculature directly regulate $\beta$-cell activity through the secretion of growth factors and other molecules. These factors come from capillary mural pericytes and endothelial cells, and have been shown to promote insulin gene expression, insulin secretion, and $\beta$-cell proliferation. This review focuses on the intimate crosstalk of the vascular cells and $\beta$ cells and its role in glucose homeostasis and diabetes.

Keywords: islet vasculature, endothelial cells, pericytes, beta-cells, Islets of Langerhans, basement membrane

\section{INTRODUCTION}

Pancreatic $\beta$-cells reside in a complex microenvironment, where they interact with other endocrine cells, as well as vascular endothelial cells and pericytes, immune cells and neurons (1-4). This review focuses on the crosstalk of $\beta$-cells with vascular cells and their role in glucose homeostasis and diabetes.

Islets, comprised of highly vascularised clusters of endocrine cells, are the functional units within the pancreas that control blood sugar levels. A dense capillary network surrounds and penetrates 
each pancreatic islet to enable glucose sensing and insulin secretion into peripheral circulation (5-8). While representing only $1-2 \%$ of the pancreatic mass, islets receive up to $20 \%$ of the direct arterial blood flow to the pancreas (9). Structural and phenotypical analysis of the pancreatic vasculature demonstrate a dense network of thick, highly-branched capillaries within islets $(1,10)$ - due to this high level of vascularisation, almost all $\beta$-cells come into contact with a capillary $(11,12)$. Pancreatic capillary structure consists of a highly-fenestrated, luminal layer of endothelial cells (13) surrounded by pericytes, which are abluminal mural cells embedded within the microvessel basement membrane (14). While there is a large body of data surrounding the roles of endothelial cells in the function of capillary beds (15-20), the specific roles of pericytes are complex and not fully understood. However, recent studies showed that pericytes play a vital role in regulating $\beta$-cell function and mass (21-24). Both types of islet vascular cells are known to promote insulin production and secretion, as well as $\beta$-cell proliferation, survival, and maturation, by secreting a variety of growth factors, components of the extracellular matrix (ECM), and other molecules $(5,22,23,25-27)$.

$\beta$-Cells do not appear to directly contact vascular cells, instead, a double-layered basement membrane comprised of extracellular matrix (ECM) glycoproteins surrounds islet capillaries in both humans (28) and mice (29), lying between the vascular and $\beta$-cells. It is apparent that $\beta$-cells specifically respond to regional contact with the capillaries. Each $\beta$-cell is structurally polarised with a basal domain at the point of capillary contact and an apical domain positioned away from the capillaries $(12,30)$. Synaptic scaffold proteins are enriched in this basal domain and insulin granule fusion is selectively targeted to this region $(12,31)$.

Vascular cells in the islets are involved in tissue inflammation and immunoregulation. Endothelial cells recruit macrophages, which in turn induce $\beta$-cell proliferation and regeneration (5-7). Although the immunoregulatory properties of pericytes in other tissues, such as the brain $(32,33)$ and kidney $(34)$, are wellestablished, whether pancreatic pericytes have similar capabilities in the islet have yet to be reported.

Accumulating evidence is showing that the interactions between vascular cells and $\beta$-cells are essential for correct islet development and become key factors in the regulation of adult islet function.

\section{ROLE OF VASCULAR CELLS IN ISLET EMBRYONIC DEVELOPMENT}

The development of many tissues, including the pancreas, depends on the interactions of various cell types. Pancreatic endocrine and exocrine cells originate from the foregut endoderm and acquire their differentiated fate in a sequential process $(21-24,35)$. Cells of the embryonic pancreatic microenvironment, including endothelial and mesenchymal cells, have been shown to regulate this process $(24,36)$.

The embryonic pancreatic mesenchyme regulates pancreas organogenesis, primarily through promoting appropriate survival and proliferation of endoderm-derived cells (37). In the final stages of embryonic development, pericytes originate from the pancreatic mesenchyme $(24,38)$, which stimulates the replication of differentiated $\beta$-cells $(37,38)$. $\beta$-Cells continue to proliferate during the neonatal stage (39), and Diphtheria Toxinmediated depletion of neonatal pericytes results in a reduced rate of $\beta$-cells replication demonstrating the influence of pericytes on $\beta$-cell expansion in both the embryonic and neonatal pancreata (22).

Endothelial cells also play a key role in islet development. The reciprocal influences of $\beta$-cells and islet endothelial cells affect development of both the vasculature (40) and $\beta$-cells $(41,42)$. Evidence indicates that $\beta$-cells are unlikely to synthesize their own ECM components, and that developmental expression of angiogenic protein VEGFA from $\beta$-cells is vital to encourage the islet vascularisation required for basement membrane formation in developing islets $(25,43)$.

Given that the islets comprise an endocrine organ and are therefore dependent on close coupling with the whole-body blood circulation, it is not surprising that vascular cells such as pericytes and endothelial cells are important for islet development. The uncovering of the roles and mechanisms of these vascular cells is interesting and potentially important for cell-based treatments for diabetes.

\section{VASCULAR REGULATION OF ADULT ISLET FUNCTION}

Exactly how pericytes and endothelial cells influence $\beta$-cell function in an adult islet is a developing area of study (44) and can, in principle, occur through a variety of effects including; capillary behaviour, secreted factors, direct contact, or ECMdriven interactions.

\section{The Role of Vascular Cells in Capillary Behaviour}

Islet blood flow is obviously important for endocrine function and allows the rapid sensing of fluctuations in blood glucose and outflow of secreted hormones. It is controlled by various nutrients and growth factors (1) and, in turn, impacts on $\beta$-cell insulin secretory activity $(4,45)$.

Approximately $40 \%$ of islet microvasculature is covered by pericytes (21) which adjust the vascular diameter and capillary blood flow by vasoconstriction and vasodilation (46). Research in this area has identified several molecules responsible for the regulation of pericyte contractile tone. For example, pericytes in the brain have been shown to express receptors for vasoactive molecules (47). Endothelial cells are known to secrete vasoactive factors, including vasodilators nitric oxide and prostacyclin as well as vasoconstrictors thromboxane and endothelin-1 (48). In the pancreas, adenosine released during ATP breakdown increases islet blood flow (49) and relaxes pericytes to dilate islet capillaries (21). In contrast, the sympathetic neurotransmitter noradrenaline induces contraction of islet capillaries and reduces 
blood flow (21). The cellular contacts and paracrine signalling between endothelial cells and pericytes that regulate vascular tone likely influence blood flow effects on $\beta$-cell endocrine function.

\section{The Role of Secreted Factors From Vascular Cells}

There is now extensive evidence that pericytes directly support $\beta$ cell function and glucose homeostasis independent of blood flow $(6,22,23,26,27)$. In vivo depletion of pericytes in the pancreas using the Diphtheria Toxin Receptor system allows study of the role in $\beta$-cell function and proliferation $(22,27)$. This depletion of pancreatic pericytes leads to glucose intolerance due to reduced islet insulin content and secretion, as well as diminished expression of cellular components required for $\beta$ cell functionality. Importantly, reduced levels of $M a f A$ and $P d x 1$, transcription factors essential for $\beta$-cell maturity, indicate $\beta$-cell de-differentiation occurs in the absence of pericytes (27). Pancreatic pericytes are further shown to secrete factors that regulate glucose-stimulated insulin secretion (GSIS). Pancreatic mural cells, i.e., pericytes and vascular smooth muscle cells, produce nerve growth factor (NGF) upon glucose stimulation (23). $\beta$-Cells express the NGF receptor tropomyosin receptor kinase A (TrkA), and the activation of this receptor promotes insulin exocytosis via glucose-induced $\beta$-cell actin remodelling (23). In humans, altered circulating NGF levels have been noted in type 2 diabetes and mutations in the TrkA gene cause decreased GSIS (50, 51). Pericytes further produce Bone morphogenetic protein 4 (BMP4), through which they potentially directly regulate $\beta$-cell function (26). While the activity of the BMP4 receptor BMPR1A is essential for proper $\beta$-cell gene expression and function (52), the involvement of pericytic BMP4 in this process was yet to be reported. The evidence of glucose-stimulated paracrine signaling between pericytes and $\beta$-cells highlights the importance of pericytes in glucose homeostasis and GSIS under physiological conditions.

Among the many factors secreted by intra-islet endothelial cells, connective tissue growth factor (CTGF) and thrombospondin (TSP)-1 have known effects on $\beta$-cells (53). CTGF, a matricellular protein active throughout the body (54), drives $\beta$-cell expansion during embryogenesis in an autocrine manner (55), thought to occur due to multiple developmentrelated transcription factor binding sites located on the CTGF gene although a mechanism has not yet been clearly defined (56). In the adult pancreas, CTGF is expressed mostly by islet endothelial cells (57). Islets that underwent partial destruction of $\beta$-cell content were treated with CTGF, leading to a $50 \%$ mass recovery attributed to the proliferative effects of the growth hormone (58). Production of TSP-1, an anti-angiogenic protein secreted by intra-islet endothelial cells, is upregulated by elevated blood glucose levels in humans (59). TSP-1-deficiency, however, leads to pancreatic hyperplasia, glucose intolerance, and impaired GSIS (60) despite knockdown-related improvements in transplanted islet revascularization (61). Rescue of TSP-1-deficient murine islets through treatment with transforming growth factor (TGF) $\beta-1$ activation inhibits the decreased glucose tolerance (60), providing insight into potential mechanisms. However, long-term deficiency of TSP-1 results in persistent dysfunction of glucose tolerance, even in the face of compensatory normalisation of $\beta$-cell mass (62). Additional molecules produced in non-pancreatic endothelial cells, such as hepatocyte growth factor (HGF), influence $\beta$-cell function as well via exocrine signaling (63).

\section{Direct Contacts Between Vascular Cells and $\beta$-Cells}

Due to the structure of the double-layered basement membrane $(28,64), \beta$-cells are unlikely to make direct contact with intraislet vascular endothelial cells or pericytes. However, there are candidate proteins that might indicate direct links are possible. For example, the pre- and post-synaptic proteins neurexin and neuroligin are expressed by vascular mural and endothelial cells (65), and have additionally been identified in $\beta$-cells (66). In neurons, these binding partners directly contact each other and mediate a plethora of biological functions (67) including synaptic organisation. Over-expression of post-synaptic receptor neuroligin-2 expression in $\beta$-cells increases GSIS (68) and promotes insulin granule docking (69). The neurexinneuroligin interactions therefore appear to be involved in regulating $\beta$-cell function. These interactions may arise through $\beta$-cell-to- $\beta$-cell contacts, but it remains an intriguing possibility that they result from interactions between the $\beta$-cells and the vascular cells. Connexins 36 and 43, which form gap junctions between cells, are similarly expressed by both endothelial and $\beta$-cells, however there is currently no evidence demonstrating direct contacts between the two cell types (44).

\section{Interactions of $\beta$-Cells With the Basement Membrane}

Various proteins of the vascular basement membrane are implicated in the regulation of $\beta$-cell function, proliferation, and expansion $(22,25,64,70)$. The basement membrane is comprised of glycoproteins including laminins, fibronectin, nidogens, and collagens $(29,71)$. The basement membrane surrounds the intra-islet capillaries and the islet capsule but is not present between endocrine cells (29); therefore, $\beta$-cells contact the basement membrane only in the regions which they contact the vasculature $(25,30)$. Evidence demonstrates that these contacts, mediated through integrin activation (31), assist in driving $\beta$-cell polarity and the targeting of insulin secretion $(12,31)$ in addition to modulating insulin gene expression (25), $\beta$-cell proliferation and survival (72), and GSIS functionality $(73,74)$.

Both endothelial and pericytes secrete ECM components that make up the islet basement membrane. Endothelial cells are responsible for the synthesis and maintenance of the ECM/ basement membrane, specifically producing laminin and collagen IV $(25,75,76)$. Pancreatic pericytes also produce an array of basement membrane components, including collagen IV, laminins, proteoglycans, and nidogen (77). In particular, pancreatic pericytes and endothelial cells both produce laminin $\alpha 4$, which promotes the expression levels of the $\beta$-cell genes Ins 1 , MafA, and Glut2, as well as GSIS (77). 
In vitro research surrounding the function of pancreatic islets is largely performed with cells derived from isolated islets, obtained through enzymatic destruction of the ECM structure $(78,79)$. Although islets retain some endothelial cell expression immediately post-isolation, the endothelial cells are rapidly diminished during culture with islets losing approximately $85 \%$ of endothelial cells within two days of culture (80). This loss of vasculature negatively impacts the endocrine function of isolated islets (25). Various lines of evidence show that attempts to preserve, restore or replace the vascular cells is beneficial to $\beta$ cells. Endothelial cell-conditioned medium in culture of dispersed $\beta$-cells improves GSIS with a laminin-dependent mechanism (81). Similarly, exposure to pericyte-conditioned medium stimulates proliferation in cultured $\beta$-cells in an integrin-dependent manner $(10,22)$. In islet transplantation, supplementing islets with endothelial cells improves revascularisation and functional outcomes compared to islets alone (82-84).

Additionally, simple incorporation of basement membrane proteins into cell cultures has repeatedly been shown to benefit cultured $\beta$-cell function and survival and is furthermore a useful approach to gain a mechanistic understanding of the processes involved. Introduction of laminins $\alpha 4$ and $\alpha 5$ to $\beta$-cells cultured in vitro on glass increases insulin gene expression and enhances GSIS, effects that are inhibited by the blockade of the integrin $\beta 1$ receptor (25). $\beta 1$ integrin has been demonstrated to regulate GSIS (85) as well as $\beta$-cell expansion (70), furthering the evidence that $\beta 1$ integrins play a key role in ECM influences on $\beta$-cell endocrine function.

In addition to affecting $\beta$-cell function, ECM contacts between islet vasculature and $\beta$-cells contribute to $\beta$-cell polarity $(12,30)$ and likely orientate the site of targeted insulin secretion to the capillaries $(12,31)$. Targeting of insulin granule fusion appears to be driven by the localisation of pre-synaptic scaffold proteins, including liprin, RIM2, piccolo, and ELKS, at the contact point of $\beta$-cells and the islet vasculature $(12,86)$ and has been shown to depend on localised $\beta 1$ integrin activation (31).

Contact between $\beta$-cells and ECM triggers focal adhesion formation downstream of $\beta 1$ integrin activation, shown via immunostaining to occur exclusively at the interface between islet blood vessels and $\beta$-cells (31). As insulin granule fusion is biased towards this interface $(12,31)$, current evidence indicates this targeting of secretion requires the focal adhesion activation and the specific involvement of focal adhesion kinase (FAK). Evidence suggests FAK as a vital signaling mediator for $\beta$-cell endocrine function, as pharmacological and genetic inhibition of FAK reduces insulin secretion (87) and disrupts secretion targeting in vitro $(12,31)$, while in vivo knockout of pancreasspecific FAK results in impaired GSIS and diminished glucose tolerance (88). Although the recruitment and activation of FAK appears essential for normal GSIS, further downstream pathways are currently unclear. Other kinase-associated pathways, such as the extracellular signal-related kinase (ERK), have similarly been shown to regulate GSIS (89), however further investigation into specific signaling cascades will be required to expand on the pathways responsible for modulating $\beta$-cell function.

\section{INVOLVEMENT OF ISLET VASCULAR CELLS IN DIABETES}

Abnormalities in the islet vasculature may drive $\beta$-cell dysfunction and diabetes progression. Changes in pericyte function and mass has been implicated in obesity and diabetes $(6,7,26,90)$. Pancreatic pericytes were recently demonstrated to express the diabetes gene transcription factor 7-like 2 (TCF7l2) (26). Polymorphism in TCF7L2 (TCF4) strongly correlates with an increased risk of type 2 diabetes (91). Pericyte-specific inactivation of Tcf7l2 impairs glucose homeostasis due to aberrant insulin production and GSIS (26). This impairment has been associated with reduced expression levels of genes associated with $\beta$-cell function and maturity, including MafA, $P d x 1$ and NeuroD1. Furthermore, pancreatic pericytes are shown to produce secreted factors in a Tcf7l2-dependent manner that potentially support $\beta$-cell function and glucose response (26). Diabetic retinopathy is characterized by an early loss of retinal pericytes under hyperglycemic conditions $(92,93)$. Loss of pericytes in the liver and brain leads to endothelial hyperplasia and abnormal vascular $(94,95)$. In the islets, progression of type 2 diabetes is associated with and may be contributed to by a gradual loss of pericytic coverage of islet capillaries (96).

As $\beta$-cell function declines and diabetes progresses, poorly controlled blood glucose levels in the form of chronic hyperglycaemia contributes significantly to abnormal protein glycation throughout the islets and other non-pancreatic tissues (97, 98). The advanced glycation end-products (AGEs) formed by this process are implicated in both worsening $\beta$-cell function as well as in development of long-term diabetic complications including diabetic retinopathy $(99,100)$, nephropathy $(100,101)$, and decreased insulin sensitivity in adipose tissues (102). Furthermore, islets/ $\beta$-cells exposed to AGEs in culture shown to have impaired GSIS and other functional defects $(103,104)$. Although not currently clear, effects on $\beta$-cell endocrine function may, in part, be mediated by effects on the ECM proteins of the basement membrane, which are generally longlived proteins and therefore more susceptible to accumulating effects of glycation.

Both type 1 and type 2 diabetes have been associated ECM abnormalities: progression of type 1 diabetes-related $\beta$-cell destruction is correlated with the amount of leukocyteinduced damage to the peri-islet basement membrane (105), while type 2 diabetes islets exhibit thicker, less branched intraislet capillaries (106) with increased fibrosis surrounding the vasculature (107). Furthermore, pancreatic pericytes can convert to myofibroblasts (96) which leads to aberrant ECM production and tissue fibrosis and would further contribute to impaired $\beta$-cell function. Specifically for AGE-related changes to ECM structure, AGE increases crosslinking of the ECM to increase stiffness (108) which may impact on the local islet environment and may inhibit cellular signaling and behaviour. Alteration in ECM stiffness is associated with dysfunction in numerous well-studied disease states, including cancer (109111), cardiovascular disease (112), and other fibrotic diseases $(113,114)$. Additionally, the receptor for AGEs (RAGE) is expressed by both endothelial cells and pericytes (115). Along 
TABLE 1 | Islet Vascular Cell Features (Summary Table).

\begin{tabular}{|c|c|c|}
\hline Feature & Endothelial cells & Pericytes \\
\hline Cell markers & $\begin{array}{l}\text { CD31 }(117,118) \\
\text { CD146, CD105 (118) } \\
\text { nephrin (119) } \\
\text { von Willebrand's factor (118) }\end{array}$ & NG2, PDGFR $\beta$ (120) \\
\hline Known effects on $\beta$-cells & $\begin{array}{l}\text { Gene expression }(25) \\
\text { Insulin secretion }(7) \\
\text { Replication }(5,25)\end{array}$ & $\begin{array}{l}\text { Gene expression }(26,27,77) \\
\text { GSIS }(23,26,27) \\
\text { Replication (22) } \\
\text { Regulation of islet blood flow (21) }\end{array}$ \\
\hline Factors secreted & $\begin{array}{l}\text { Connective tissue growth factor (CTGF) (53) } \\
\text { Thrombospondin (TSP)-1 (60) }\end{array}$ & $\begin{array}{l}\text { Nerve growth factor (NGF) (23) } \\
\text { Bone morphogenetic protein } 4 \\
\text { (BMP4) (26) }\end{array}$ \\
\hline $\begin{array}{l}\text { Basement membrane } \\
\text { components produced }\end{array}$ & $\begin{array}{l}\text { Collagen IV } \\
\text { Laminin } \alpha 4 \\
\text { Laminin } \alpha 5(25)\end{array}$ & $\begin{array}{l}\text { Collagen IV } \\
\text { Laminin } \alpha 2 \\
\text { Laminin } \alpha 4 \\
\text { Nidogens } \\
\text { Perlecans (77) }\end{array}$ \\
\hline Immunoregulatory function & Recruit pancreatic macrophages (5) & $\begin{array}{l}\text { Unknown in pancreas } \\
\text { Leukocyte trafficking/activation in } \\
\text { brain and kidney }(32-34) \\
\text { Production of anti-inflammatory } \\
\text { factors }(33,121,122)\end{array}$ \\
\hline Implications in diabetes & $\begin{array}{l}\text { Activation of AGE receptors may contribute to progressive complications (115) } \\
\text { Alterations of vasculature in diabetic islets (107) and secreted basement membrane (106) } \\
\text { associated with disease-related islet damage (105) and malfunction (107) }\end{array}$ & $\begin{array}{l}\text { Type } 2 \text { diabetes is associated with a } \\
\text { reduced density ( } 21) \\
\text { Support of } \beta \text {-cells depends on the } \\
\text { diabetes gene TCF7L2 (26) } \\
\text { Transform to myofibroblast during } \\
\text { stress (96) }\end{array}$ \\
\hline
\end{tabular}

with AGE-triggered basement membrane modification (116), AGE receptors are thought to be involved in the triggering of retinal pericyte apoptosis that occurs in diabetic retinopathy (115) - it may be that islet pericytes undergo similar apoptotic signaling, further impacting pancreatic endocrine function.

\section{CONCLUDING REMARKS}

The islet vasculature affects various aspects of pancreatic function and GSIS through both blood flow-dependent and -independent pathways as summarized in Table 1. While each of the vascular components, namely endothelial cell and pericytes, are known to individually support $\beta$-cell function, whether these cells have a synergistic effect are yet to be directly studied. For example, heterotypic interactions of pericytes and endothelial cells are required for vascular basement membrane assembly in many tissues but this has not yet been shown in the pancreas. Further, whether direct interactions between islet endothelial cells and pericytes affect the other's production and

\section{REFERENCES}

1. Aamodt KI, Powers AC. Signals in the Pancreatic Islet Microenvironment Influence $\beta$-Cell Proliferation. Diabetes Obes Metab (2017) 19 Suppl 1(Suppl 1):124-36. doi: 10.1111/dom.13031

2. Almaça J, Caicedo A, Landsman L. Beta Cell Dysfunction in Diabetes: The Islet Microenvironment as an Unusual Suspect. Diabetologia (2020) 63 (10):2076-85. doi: 10.1007/s00125-020-05186-5 secretion of factors, thus influencing their ability to support $\beta$ cells, is yet to be uncovered.

\section{AUTHOR CONTRIBUTIONS}

$\mathrm{GB}, \mathrm{CB}, \mathrm{PT}$, and LL wrote and edited the manuscript. All authors contributed to the article and approved the submitted version.

\section{FUNDING}

Project funding was obtained from the National Health and Medical Research Council (APP1128273 and APP1146788; to PT), the Israel Science Foundation (ISF; Grant agreement no. 1605/18; to LL), and the European Union's Horizon 2020 Research and Innovation Programme (Grant agreement no. 800981; to LL). 
Factor-a Signaling, Promotes $\beta$ Cell Regeneration. Cell Metab (2014) 19 (3):498-511. doi: 10.1016/j.cmet.2014.02.001

6. Hayes KL. Pericytes in Type 2 Diabetes. In: A Birbrair, editor. Pericyte Biology in Disease. Cham: Springer International Publishing (2019). p. 26578. doi: 10.1007/978-3-030-16908-4_12

7. Richards OC, Raines SM, Attie AD. The Role of Blood Vessels, Endothelial Cells, and Vascular Pericytes in Insulin Secretion and Peripheral Insulin Action. Endocrine Rev (2010) 31(3):343-63. doi: 10.1210/er.2009-0035

8. Dybala MP, Kuznetsov A, Motobu M, Hendren-Santiago BK, Philipson LH, Chervonsky AV, et al. Integrated Pancreatic Blood Flow: Bidirectional Microcirculation Between Endocrine and Exocrine Pancreas. Diabetes (2020) 69(7):1439-50. doi: 10.2337/db19-1034

9. Lifson N, Lassa CV, Dixit PK. Relation Between Blood Flow and Morphology in Islet Organ of Rat Pancreas. Am J Physiol (1985) 249(1 Pt 1):E43-8. doi: 10.1152/ajpendo.1985.249.1.E43

10. Chen J, Lippo L, Labella R, Tan SL, Marsden BD, Dustin ML, et al. Decreased Blood Vessel Density and Endothelial Cell Subset Dynamics During Ageing of the Endocrine System. EMBO J (2020) 40(1):e105242. doi: 10.15252/ embj.2020105242

11. Bonner-Weir S, Sullivan BA, Weir GC. Human Islet Morphology Revisited: Human and Rodent Islets Are Not So Different After All. J Histochem Cytochem (2015) 63(8):604-12. doi: 10.1369/0022155415570969

12. Cottle L, Gan WJ, Gilroy I, Samra JS, Gill AJ, Loudovaris T, et al. Structural and Functional Polarisation of Human Pancreatic Beta Cells in Islets From Organ Donors With and Without Type 2 Diabetes. Diabetologia (2021) 61829. doi: $10.1007 / \mathrm{s} 00125-020-05345-8$

13. Kolka CM, Bergman RN. The Barrier Within: Endothelial Transport of Hormones. Physiology (2012) 27(4):237-47. doi: 10.1152/physiol.00012.2012

14. Armulik A, Genové G, Betsholtz C. Pericytes: Developmental, Physiological, and Pathological Perspectives, Problems, and Promises. Dev Cell (2011) 21 (2):193-215. doi: 10.1016/j.devcel.2011.07.001

15. Alberts B, Johnson A, Lewis J, Raff M, Roberts K, Walter P. Blood Vessels and Endothelial Cells. In: Biology of the Cell, 4th ed. New York: Garland Science (2002).

16. Rajendran $P$, Rengarajan $T$, Thangavel J, Nishigaki $Y$, Sakthisekaran D, Sethi G, et al. The Vascular Endothelium and Human Diseases. Int J Biol Sci (2013) 9(10):1057-69. doi: 10.7150/ijbs.7502

17. Deanfield John E, Halcox Julian P, Rabelink Ton J. Endothelial Function and Dysfunction. Circulation (2007) 115(10):1285-95. doi: 10.1161/ CIRCULATIONAHA.106.652859

18. Michiels C. Endothelial Cell Functions. J Cell Physiol (2003) 196(3):430-43. doi: $10.1002 / j c p .10333$

19. Moradipoor S, Ismail P, Etemad A, Sulaiman WAW, Ahmadloo S. Expression Profiling of Genes Related to Endothelial Cells Biology in Patients With Type 2 Diabetes and Patients With Prediabetes. BioMed Res Int (2016). doi: $10.1155 / 2016 / 1845638$

20. Félétou M. Multiple Functions of the Endothelial Cells. In: . The Endothelium: Part 1: Multiple Functions of the Endothelial Cells-Focus on Endothelium-Derived Vasoactive Mediators. San Rafael (CA: Morgan \& Claypool Life Sciences (2011). doi: 10.4199/C00031ED1V01Y 201105 ISP019

21. Almaça J, Weitz J, Rodriguez-Diaz R, Pereira E, Caicedo A. The Pericyte of the Pancreatic Islet Regulates Capillary Diameter and Local Blood Flow. Cell Metab (2018) 27(3):630-44.e4. doi: 10.1016/j.cmet.2018.02.016

22. Epshtein A, Rachi E, Sakhneny L, Mizrachi S, Baer D, Landsman L. Neonatal Pancreatic Pericytes Support $\beta$-Cell Proliferation. Mol Metab (2017) 6 (10):1330-8. doi: 10.1016/j.molmet.2017.07.010

23. Houtz J, Borden P, Ceasrine A, Minichiello L, Kuruvilla R. Neurotrophin Signaling is Required for Glucose-Induced Insulin Secretion. Dev Cell (2016) 39(3):329-45. doi: 10.1016/j.devcel.2016.10.003

24. Sakhneny L, Khalifa-Malka L, Landsman L. Pancreas Organogenesis: Approaches to Elucidate the Role of Epithelial-Mesenchymal Interactions. Semin Cell Dev Biol (2019) 92:89-96. doi: 10.1016/ j.semcdb2018.08.012

25. Nikolova G, Jabs N, Konstantinova I, Domogatskaya A, Tryggvason K, Sorokin L, et al. The Vascular Basement Membrane: A Niche for Insulin Gene Expression and Beta Cell Proliferation. Dev Cell (2006) 10(3):397-405. doi: 10.1016/j.devcel.2006.01.015
26. Sakhneny L, Rachi E, Epshtein A, Guez HC, Wald-Altman S, Lisnyansky M, et al. Pancreatic Pericytes Support $\beta$-Cell Function in a Tcf7l2-Dependent Manner. Diabetes (2018) 67(3):437-47. doi: 10.2337/db17-0697

27. Sasson A, Rachi E, Sakhneny L, Baer D, Lisnyansky M, Epshtein A, et al. Islet Pericytes are Required for $\beta$-Cell Maturity. Diabetes (2016) 65(10):3008-14. doi: $10.2337 / \mathrm{db} 16-0365$

28. Virtanen I, Banerjee M, Palgi J, Korsgren O, Lukinius A, Thornell LE, et al. Blood Vessels of Human Islets of Langerhans are Surrounded by a Double Basement Membrane. Diabetologia (2008) 51(7):1181-91. doi: 10.1007/ s00125-008-0997-9

29. Lammert E, Thorn P. The Role of the Islet Niche on Beta Cell Structure and Function. J Mol Biol (2020) 432(5):1407-18. doi: 10.1016/j.jmb.2019.10.032

30. Gan WJ, Zavortink M, Ludick C, Templin R, Webb R, Webb R, et al. Cell Polarity Defines Three Distinct Domains in Pancreatic $\beta$-Cells. J Cell Sci (2017) 130(1):143-51. doi: 10.1242/jcs. 185116

31. Gan WJ, Do OH, Cottle L, Ma W, Kosobrodova E, Cooper-White J, et al. Local Integrin Activation in Pancreatic $\beta$ Cells Targets Insulin Secretion to the Vasculature. Cell Rep (2018) 24(11):2819-26.e3. doi: 10.1016/ j.celrep.2018.08.035

32. Balabanov R, Beaumont T, Dore-Duffy P. Role of Central Nervous System Microvascular Pericytes in Activation of Antigen-Primed Splenic TLymphocytes. J Neurosci Res (1999) 55(5):578-87. doi: 10.1002/(SICI) 1097-4547(19990301)55:5<578::AID-JNR5>3.0.CO;2-E

33. Rustenhoven J, Jansson D, Smyth LC, Dragunow M. Brain Pericytes as Mediators of Neuroinflammation. Trends Pharmacol Sci (2017) 38(3):291304. doi: 10.1016/j.tips.2016.12.001

34. Leaf IA, Nakagawa S, Johnson BG, Cha JJ, Mittelsteadt K, Guckian KM, et al. Pericyte MyD88 and IRAK4 Control Inflammatory and Fibrotic Responses to Tissue Injury. J Clin Invest (2017) 127(1):321-34. doi: 10.1172/JCI87532

35. Pan FC, Wright C. Pancreas Organogenesis: From Bud to Plexus to Gland. Dev Dyn (2011) 240(3):530-65. doi: 10.1002/dvdy.22584

36. Cleaver O, Dor Y. Vascular Instruction of Pancreas Development. Development (2012) 139(16):2833-43. doi: 10.1242/dev.065953

37. Landsman L, Nijagal A, Whitchurch TJ, Vanderlaan RL, Zimmer WE, Mackenzie TC, et al. Pancreatic Mesenchyme Regulates Epithelial Organogenesis Throughout Development. PloS Biol (2011) 9(9):e1001143. doi: 10.1371/journal.pbio.1001143

38. Harari N, Sakhneny L, Khalifa-Malka L, Busch A, Hertel KJ, Hebrok M, et al. Pancreatic Pericytes Originate From the Embryonic Pancreatic Mesenchyme. Dev Biol (2019) 449(1):14-20. doi: 10.1016/ j.ydbio.2019.01.020

39. Wang P, Fiaschi-Taesch NM, Vasavada RC, Scott DK, García-Ocaña A, Stewart AF. Diabetes Mellitus-Advances and Challenges in Human $\beta$-Cell Proliferation. Nat Rev Endocrinol (2015) 11(4):201-12. doi: 10.1038/ nrendo.2015.9

40. Xiong Y, Scerbo MJ, Seelig A, Volta F, Brien N, Dicker A, et al. Islet Vascularization is Regulated by Primary Endothelial Cilia Via VEGF-Adependent Signaling. eLife (2020) 9:NA. doi: 10.7554/eLife.56914

41. Lammert E, Cleaver O, Melton D. Induction of Pancreatic Differentiation by Signals From Blood Vessels. Science (2001) 294(5542):564-7. doi: 10.1126/ science. 1064344

42. Yoshitomi H, Zaret KS. Endothelial Cell Interactions Initiate Dorsal Pancreas Development by Selectively Inducing the Transcription Factor Ptfla. Development (2004) 131(4):807. doi: 10.1242/dev.00960

43. Reinert RB, Brissova M, Shostak A, Pan FC, Poffenberger G, Cai Q, et al. Vascular Endothelial Growth Factor-A and Islet Vascularization Are Necessary in Developing, But Not Adult, Pancreatic Islets. Diabetes (2013) 62(12):4154. doi: 10.2337/db13-0071

44. Peiris H, Bonder CS, Coates PTH, Keating DJ, Jessup CF. The $\beta$-Cell/Ec Axis: How Do Islet Cells Talk to Each Other? Diabetes (2014) 63(1):3. doi: 10.2337/db13-0617

45. Dai C, Brissova M, Reinert RB, Nyman L, Liu EH, Thompson C, et al. Pancreatic Islet Vasculature Adapts to Insulin Resistance Through Dilation and Not Angiogenesis. Diabetes (2013) 62(12):4144-53. doi: 10.2337/db121657

46. Rucker HK, Wynder HJ, Thomas WE. Cellular Mechanisms of CNS Pericytes. Brain Res Bull (2000) 51(5):363-9. doi: 10.1016/S0361-9230(99) 00260-9 
47. Winkler EA, Bell RD, Zlokovic BV. Central Nervous System Pericytes in Health and Disease. Nat Neurosci (2011) 14(11):1398-405. doi: 10.1038/ nn.2946

48. Sandoo A, van Zanten JJCSV, Metsios GS, Carroll D, Kitas GD. The Endothelium and its Role in Regulating Vascular Tone. Open Cardiovasc Med J (2010) 4:302-12. doi: 10.2174/1874192401004010302

49. Carlsson PO, Olsson R, Källskog O, Bodin B, Andersson A, Jansson L. Glucose-Induced Islet Blood Flow Increase in Rats: Interaction Between Nervous and Metabolic Mediators. Am J Physiol Endocrinol Metab (2002) 283(3):E457-64. doi: 10.1152/ajpendo.00044.2002

50. Bulló M, Peeraully MR, Trayhurn P, Folch J, Salas-Salvadó J. Circulating Nerve Growth Factor Levels in Relation to Obesity and the Metabolic Syndrome in Women. Eur J Endocrinol (2007) 157(3):303-10. doi: 10.1530/EJE-06-0716

51. Kim HC, Cho YJ, Ahn CW, Park KS, Kim JC, Nam JS, et al. Nerve Growth Factor and Expression of its Receptors in Patients With Diabetic Neuropathy. Diabetic Med (2009) 26(12):1228-34. doi: 10.1111/j.14645491.2009.02856.x

52. Goulley J, Dahl U, Baeza N, Mishina Y, Edlund H. Bmp4-BMPR1A Signaling in Beta Cells is Required for and Augments Glucose-Stimulated Insulin Secretion. Cell Metab (2007) 5(3):207-19. doi: 10.1016/ j.cmet.2007.01.009

53. Hogan MF, Hull RL. The Islet Endothelial Cell: A Novel Contributor to Beta Cell Secretory Dysfunction in Diabetes. Diabetologia (2017) 60(6):952-9. doi: $10.1007 / \mathrm{s} 00125-017-4272-9$

54. Chen Z, Zhang N, Chu HY, Yu Y, Zhang Z-K, Zhang G, et al. Connective Tissue Growth Factor: From Molecular Understandings to Drug Discovery. Front Cell Dev Biol (2020) 8(1239). doi: 10.3389/fcell.2020. 593269

55. Guney MA, Petersen CP, Boustani A, Duncan MR, Gunasekaran U, Menon R, et al. Connective Tissue Growth Factor Acts Within Both Endothelial Cells and $\beta$ Cells to Promote Proliferation of Developing $\beta$ Cells. Proc Natl Acad Sci (2011) 108(37):15242-7. doi: 10.1073/pnas.1100 072108

56. Charrier A, Brigstock DR. Regulation of Pancreatic Function by Connective Tissue Growth Factor (CTGF, CCN2). Cytokine Growth Factor Rev (2013) 24(1):59-68. doi: 10.1016/j.cytogfr.2012.07.001

57. Crawford LA, Guney MA, Oh YA, Deyoung RA, Valenzuela DM, Murphy AJ, et al. Connective Tissue Growth Factor (CTGF) Inactivation Leads to Defects in Islet Cell Lineage Allocation and Beta-Cell Proliferation During Embryogenesis. Mol Endocrinol (2009) 23(3):324-36. doi: 10.1210/me.20080045

58. Riley KG, Pasek RC, Maulis MF, Peek J, Thorel F, Brigstock DR, et al. Connective Tissue Growth Factor Modulates Adult $\beta$-Cell Maturity and Proliferation to Promote $\beta$-Cell Regeneration in Mice. Diabetes (2015) 64 (4):1284-98. doi: 10.2337/db14-1195

59. Dubois S, Madec AM, Mesnier A, Armanet M, Chikh K, Berney T, et al. Glucose Inhibits Angiogenesis of Isolated Human Pancreatic Islets. J Mol Endocrinol (2010) 45(2):99-105. doi: 10.1677/JME-10-0020

60. Olerud J, Mokhtari D, Johansson M, Christoffersson G, Lawler J, Welsh N, et al. Thrombospondin-1: An Islet Endothelial Cell Signal of Importance for $\beta$-Cell Function. Diabetes (2011) 60(7):1946-54. doi: 10.2337/db100277

61. Olerud J, Johansson M, Lawler J, Welsh N, Carlsson P-O. Improved Vascular Engraftment and Graft Function After Inhibition of the Angiostatic Factor Thrombospondin-1 in Mouse Pancreatic Islets. Diabetes (2008) 57(7):1870. doi: 10.2337/db07-0724

62. Drott CJ, Olerud J, Emanuelsson H, Christoffersson G, Carlsson P-O. Sustained Beta-Cell Dysfunction But Normalized Islet Mass in Aged Thrombospondin-1 Deficient Mice. PloS One (2012) 7(10):e47451-e. doi: 10.1371/journal.pone.0047451

63. Oliveira AG, Araújo TG, Carvalho B, Rocha GZ, Santos A, Saad MJA. The Role of Hepatocyte Growth Factor (HGF) in Insulin Resistance and Diabetes. Front Endocrinol (Lausanne) (2018) 9:503-. doi: 10.3389/ fendo.2018.00503

64. Lammert E, Kragl M. Basement Membrane in Pancreatic Islet Function. In: MS Islam, editor. Islets of Langerhans. Dordrecht: Springer Netherlands (2015). p. 39-58. doi: 10.1007/978-94-007-6686-0_8
65. Bottos A, Destro E, Rissone A, Graziano S, Cordara G, Assenzio B, et al. The Synaptic Proteins Neurexins and Neuroligins are Widely Expressed in the Vascular System and Contribute to its Functions. Proc Natl Acad Sci United States America (2009) 106(49):20782-7. doi: 10.1073/pnas.08095 10106

66. Mosedale M, Egodage S, Calma RC, Chi N-W, Chessler SD. Neurexin-1 $\alpha$ Contributes to Insulin-Containing Secretory Granule Docking. J Biol Chem (2012) 287(9):6350-61. doi: 10.1074/jbc.M111.299081

67. Munder A, Israel LL, Kahremany S, Ben-Shabat-Binyamini R, Zhang C, Kolitz-Domb M, et al. Mimicking Neuroligin-2 Functions in $\beta$-Cells by Functionalized Nanoparticles as a Novel Approach for Antidiabetic Therapy. ACS Appl Mater Interfaces (2017) 9(2):1189-206. doi: 10.1021/ acsami.6b10568

68. Suckow AT, Comoletti D, Waldrop MA, Mosedale M, Egodage S, Taylor P, et al. Expression of Neurexin, Neuroligin, and Their Cytoplasmic Binding Partners in the Pancreatic Beta-Cells and the Involvement of Neuroligin in Insulin Secretion. Endocrinology (2008) 149(12):6006-17. doi: 10.1210/ en.2008-0274

69. Zhang C, Suckow AT, Chessler SD. Altered Pancreatic Islet Function and Morphology in Mice Lacking the Beta-cell Surface Protein Neuroligin-2. PloS One (2013) 8(6):e65711-e. doi: 10.1371/journal.pone.0065711

70. Diaferia GR, Jimenez-Caliani AJ, Ranjitkar P, Yang W, Hardiman G, Rhodes CJ, et al. $\beta 1$ Integrin is a Crucial Regulator of Pancreatic $\beta$-Cell Expansion. Development (2013) 140(16):3360-72. doi: 10.1242/dev.098533

71. Ma F, Tremmel DM, Li Z, Lietz CB, Sackett SD, Odorico JS, et al. In Depth Quantification of Extracellular Matrix Proteins From Human Pancreas. J Proteome Res (2019) 18(8):3156-65. doi: 10.1021/acs. jproteome.9b00241

72. Kilkenny DM, Rocheleau JV. Fibroblast Growth Factor Receptor-1 Signaling in Pancreatic Islet Beta-Cells is Modulated by the Extracellular Matrix. Mol Endocrinol (Baltimore Md) (2008) 22(1):196-205. doi: 10.1210/me.20070241

73. Halban PA, Wollheim CB, Blondel B, Meda P, Niesor EN, Mintz DH. The Possible Importance of Contact Between Pancreatic Islet Cells for the Control of Insulin Release*. Endocrinology (1982) 111(1):86-94. doi: 10.1210/endo-111-1-86

74. Kaido T, Yebra M, Cirulli V, Rhodes C, Diaferia G, Montgomery AM. Impact of Defined Matrix Interactions on Insulin Production by Cultured Human $\beta$-Cells. Diabetes (2006) 55(10):2723. doi: 10.2337/ db06-0120

75. Kusuma S, Zhao S, Gerecht S. The Extracellular Matrix is a Novel Attribute of Endothelial Progenitors and of Hypoxic Mature Endothelial Cells. FASEB $J$ (2012) 26(12):4925-36. doi: 10.1096/fj.12-209296

76. Vartanian KB, Kirkpatrick SJ, McCarty OJ, Vu TQ, Hanson SR, Hinds MT. Distinct Extracellular Matrix Microenvironments of Progenitor and Carotid Endothelial Cells. J BioMed Mater Res A (2009) 91(2):528-39. doi: 10.1002/ jbm.a. 32225

77. Sakhneny L, Epshtein A, Landsman L. Pericytes Contribute to the Islet Basement Membranes to Promote Beta-Cell Gene Expression. Sci Rep (2021) 11(1):2378. doi: 10.1038/s41598-021-81774-8

78. Villarreal D, Pradhan G, Wu C-S, Allred CD, Guo S, Sun Y. A Simple High Efficiency Protocol for Pancreatic Islet Isolation From Mice. JoVE 2019(150): e57048. doi: 10.3791/57048

79. Ng NHJ, Tan WX, Koh YX, Teo A. Human Islet Isolation and Distribution Efforts for Clinical and Basic Research. OBM Transplant (2019) 3:1-. doi: 10.21926/obm.transplant.1902068

80. Nyqvist D, Köhler M, Wahlstedt H, Berggren P-O. Donor Islet Endothelial Cells Participate in Formation of Functional Vessels Within Pancreatic Islet Grafts. Diabetes (2005) 54(8):2287. doi: 10.2337/diabetes.54.8.2287

81. Johansson A, Lau J, Sandberg M, Borg LA, Magnusson PU, Carlsson PO. Endothelial Cell Signalling Supports Pancreatic Beta Cell Function in the Rat. Diabetologia (2009) 52(11):2385-94. doi: 10.1007/s00125-009$1485-6$

82. Kang S, Park HS, Jo A, Hong SH, Lee HN, Lee YY, et al. Endothelial Progenitor Cell Cotransplantation Enhances Islet Engraftment by Rapid Revascularization. Diabetes (2012) 61(4):866. doi: 10.2337/db10-1492

83. Oh BJ, Oh SH, Jin SM, Suh S, Bae JC, Park C-G, et al. Co-Transplantation of Bone Marrow-Derived Endothelial Progenitor Cells Improves 
Revascularization and Organization in Islet Grafts. Am J Transplant (2013) 13(6):1429-40. doi: 10.1111/ajt.12222

84. Penko D, Rojas-Canales D, Mohanasundaram D, Peiris HS, Sun WY, Drogemuller CJ, et al. Endothelial Progenitor Cells Enhance Islet Engraftment, Influence $\beta$-Cell Function, and Modulate Islet Connexin 36 Expression. Cell Transplant (2015) 24(1):37-48. doi: 10.3727/ 096368913 X673423

85. Riopel M, Krishnamurthy M, Li J, Liu S, Leask A, Wang R. Conditional B1Integrin-Deficient Mice Display Impaired Pancreatic $\beta$ Cell Function. J Pathol (2011) 224(1):45-55. doi: 10.1002/path.2849

86. Low JT, Zavortink M, Mitchell JM, Gan WJ, Do OH, Schwiening CJ, et al. Insulin Secretion From Beta Cells in Intact Mouse Islets is Targeted Towards the Vasculature. Diabetologia (2014) 57(8):1655-63. doi: 10.1007/s00125014-3252-6

87. Rondas D, Tomas A, Halban PA. Focal Adhesion Remodeling is Crucial for Glucose-Stimulated Insulin Secretion and Involves Activation of Focal Adhesion Kinase and Paxillin. Diabetes (2011) 60(4):1146-57. doi: 10.2337/db10-0946

88. Cai EP, Casimir M, Schroer SA, Luk CT, Shi SY, Choi D, et al. In Vivo Role of Focal Adhesion Kinase in Regulating Pancreatic $\beta$-Cell Mass and Function Through Insulin Signaling, Actin Dynamics, and Granule Trafficking. Diabetes (2012) 61(7):1708-18. doi: 10.2337/db11-1344

89. Longuet C, Broca C, Costes S, Hani EH, Bataille D, Dalle SP. Extracellularly Regulated Kinases 1/2 (P44/42 Mitogen-Activated Protein Kinases) Phosphorylate Synapsin I and Regulate Insulin Secretion in the MIN6 $\beta$ Cell Line and Islets of Langerhans. Endocrinology (2005) 146(2):643-54. doi: 10.1210/en.2004-0841

90. Mahdi T, Hänzelmann S, Salehi A, Muhammed SJ, Reinbothe TM, Tang Y, et al. Secreted Frizzled-Related Protein 4 Reduces Insulin Secretion and is Overexpressed in Type 2 Diabetes. Cell Metab (2012) 16(5):625-33. doi: 10.1016/j.cmet.2012.10.009

91. Grant SF, Thorleifsson G, Reynisdottir I, Benediktsson R, Manolescu A, Sainz J, et al. Variant of Transcription Factor 7-Like 2 (TCF7L2) Gene Confers Risk of Type 2 Diabetes. Nat Genet (2006) 38(3):320-3. doi: $10.1038 /$ ng 1732

92. Bergers G, Song S. The Role of Pericytes in Blood-Vessel Formation and Maintenance. Neuro Oncol (2005) 7(4):452-64. doi: 10.1215/ S1152851705000232

93. Tu Z, Li Y, Smith DS, Sheibani N, Huang S, Kern T, et al. Retinal Pericytes Inhibit Activated T Cell Proliferation. Invest Ophthalmol Vis Sci (2011) 52 (12):9005-10. doi: 10.1167/iovs.11-8008

94. Hellström M, Gerhardt H, Kalén M, Li X, Eriksson U, Wolburg H, et al. Lack of Pericytes Leads to Endothelial Hyperplasia and Abnormal Vascular Morphogenesis. J Cell Biol (2001) 153(3):543-54. doi: 10.1083/jcb.153.3.543

95. Raines SM, Richards OC, Schneider LR, Schueler KL, Rabaglia ME, Oler AT, et al. Loss of PDGF-B Activity Increases Hepatic Vascular Permeability and Enhances Insulin Sensitivity. Am J Physiol Endocrinol Metab (2011) 301(3): E517-26. doi: 10.1152/ajpendo.00241.2011

96. Mateus Gonçalves L, Pereira E, Werneck de Castro JP, Bernal-Mizrachi E, Almaça J. Islet Pericytes Convert Into Profibrotic Myofibroblasts in a Mouse Model of Islet Vascular Fibrosis. Diabetologia (2020) 63(8):1564-75. doi: 10.1007/s00125-020-05168-7

97. Nowotny K, Jung T, Höhn A, Weber D, Grune T. Advanced Glycation End Products and Oxidative Stress in Type 2 Diabetes Mellitus. Biomolecules (2015) 5(1):194-222. doi: 10.3390/biom5010194

98. Strieder-Barboza C, Baker NA, Flesher CG, Karmakar M, Neeley CK, Polsinelli D, et al. Advanced Glycation End-Products Regulate Extracellular Matrix-Adipocyte Metabolic Crosstalk in Diabetes. Sci Rep (2019) 9(1):19748. doi: 10.1038/s41598-019-56242-z

99. Chen M, Curtis TM, Stitt AW. Advanced Glycation End Products and Diabetic Retinopathy. Curr Med Chem (2013) 20(26):3234-40. doi: 10.2174/ 09298673113209990025

100. Genuth S, Sun W, Cleary P, Sell DR, Dahms W, Malone J, et al. Glycation and Carboxymethyllysine Levels in Skin Collagen Predict the Risk of Future 10-Year Progression of Diabetic Retinopathy and Nephropathy in the Diabetes Control and Complications Trial and Epidemiology of Diabetes Interventions and Complications Participants With Type 1 Diabetes. Diabetes (2005) 54(11):3103-11. doi: 10.2337/diabetes.54.11.3103
101. Suzuki D, Toyoda M, Yamamoto N, Miyauchi M, Katoh M, Kimura M, et al. Relationship Between the Expression of Advanced Glycation End-Products (AGE) and the Receptor for AGE (Rage) mRNA in Diabetic Nephropathy. Intern Med (2006) 45(7):435-41. doi: 10.2169/internalmedicine.45.1557

102. Unoki H, Bujo H, Yamagishi S, Takeuchi M, Imaizumi T, Saito Y. Advanced Glycation End Products Attenuate Cellular Insulin Sensitivity by Increasing the Generation of Intracellular Reactive Oxygen Species in Adipocytes. Diabetes Res Clin Pract (2007) 76(2):236-44. doi: 10.1016/ j.diabres.2006.09.016

103. Coughlan MT, Yap FYT, Tong DCK, Andrikopoulos S, Gasser A, ThallasBonke V, et al. Advanced Glycation End Products are Direct Modulators of [Beta]-Cell Function. Diabetes (2011) 60(10):2523-32. doi: 10.2337/db101033

104. Lin N, Zhang H, Su Q. Advanced Glycation End-Products Induce Injury to Pancreatic Beta Cells Through Oxidative Stress. Diabetes Metab (2012) 38 (3):250-7. doi: 10.1016/j.diabet.2012.01.003

105. Bogdani M, Korpos E, Simeonovic CJ, Parish CR, Sorokin L, Wight TN. Extracellular Matrix Components in the Pathogenesis of Type 1 Diabetes. Curr Diabetes Rep (2014) 14(12):552. doi: 10.1007/s11892-014-0552-7

106. Brissova M, Shostak A, Fligner CL, Revetta FL, Washington MK, Powers AC, et al. Human Islets Have Fewer Blood Vessels Than Mouse Islets and the Density of Islet Vascular Structures is Increased in Type 2 Diabetes. J Histochem Cytochem (2015) 63(8):637-45. doi: 10.1369/00221554155 73324

107. Hayden MR, Patel K, Habibi J, Gupta D, Tekwani SS, Whaley-Connell A, et al. Attenuation of Endocrine-Exocrine Pancreatic Communication in Type 2 Diabetes: Pancreatic Extracellular Matrix Ultrastructural Abnormalities. J Cardiometab Syndr (2008) 3(4):234-43. doi: 10.1111/ j.1559-4572.2008.00024.x

108. Sant S, Wang D, Agarwal R, Dillender S, Ferrell N. Glycation Alters the Mechanical Behavior of Kidney Extracellular Matrix. Matrix Biol Plus (2020) 8:100035. doi: 10.1016/j.mbplus.2020.100035

109. Bordeleau F, Mason B, Lollis E, Mazzola M, Zanotelli M, Somasegar S, et al. Matrix Stiffening Promotes a Tumor Vasculature Phenotype. Proc Natl Acad Sci (2016) 114:201613855. doi: 10.1073/pnas.1613855114

110. Cox TR, Erler JT. Remodeling and Homeostasis of the Extracellular Matrix: Implications for Fibrotic Diseases and Cancer. Dis Models Mech (2011) 4 (2):165. doi: $10.1242 / \mathrm{dmm} .004077$

111. Lu P, Weaver VM, Werb Z. The Extracellular Matrix: A Dynamic Niche in Cancer Progression. J Cell Biol (2012) 196(4):395-406. doi: 10.1083/ jcb.201102147

112. Hegab Z, Gibbons S, Neyses L, Mamas MA. Role of Advanced Glycation End Products in Cardiovascular Disease. World J Cardiol (2012) 4(4):90-102. doi: 10.4330/wjc.v4.i4.90

113. Hewlett JC, Kropski JA, Blackwell TS. Idiopathic Pulmonary Fibrosis: Epithelial-mesenchymal Interactions and Emerging Therapeutic Targets. Matrix Biol (2018) 71-72:112-27. doi: 10.1016/j.matbio.2018.03.021

114. Pakshir P, Hinz B. The Big Five in Fibrosis: Macrophages, Myofibroblasts, Matrix, Mechanics, and Miscommunication. Matrix Biol (2018) 68-69:8193. doi: 10.1016/j.matbio.2018.01.019

115. Chibber R, Molinatti PA, Rosatto N, Lambourne B, Kohner EM. Toxic Action of Advanced Glycation End Products on Cultured Retinal Capillary Pericytes and Endothelial Cells: Relevance to Diabetic Retinopathy. Diabetologia (1997) 40(2):156-64. doi: 10.1007/s001250050657

116. Nagaraj RH, Oya-Ito T, Bhat M, Liu B. Dicarbonyl Stress and Apoptosis of Vascular Cells: Prevention by Alphab-Crystallin. Ann N Y Acad Sci (2005) 1043:158-65. doi: 10.1196/annals.1333.020

117. Albelda SM, Oliver PD, Romer LH, Buck CA. EndoCAM: A Novel Endothelial Cell-Cell Adhesion Molecule. J Cell Biol (1990) 110(4):122737. doi: $10.1083 /$ jcb.110.4.1227

118. Favaro E, Bottelli A, Lozanoska-Ochser B, Ferioli E, Huang GC, Klein N, et al. Primary and Immortalised Human Pancreatic Islet Endothelial Cells: Phenotypic and Immunological Characterisation. Diabetologia (2005) 48 (12):2552-62. doi: 10.1007/s00125-005-0008-3

119. Zanone MM, Favaro E, Doublier S, Lozanoska-Ochser B, Deregibus MC, Greening J, et al. Expression of Nephrin by Human Pancreatic Islet Endothelial Cells. Diabetologia (2005) 48(9):1789-97. doi: 10.1007/s00125005-1865-5 
120. Armulik A, Abramsson A, Betsholtz C. Endothelial/Pericyte Interactions. Circ Res (2005) 97(6):512-23. doi: 10.1161/01.RES.0000182903.16652.d7

121. Fu AK, Hung KW, Yuen MY, Zhou X, Mak DS, Chan IC, et al. Il-33 Ameliorates Alzheimer's Disease-Like Pathology and Cognitive Decline. Proc Natl Acad Sci USA (2016) 113(19):E2705-13. doi: 10.1073/ pnas. 1604032113

122. Yang Y, Andersson P, Hosaka K, Zhang Y, Cao R, Iwamoto H, et al. The PDGF-BB-SOX7 Axis-Modulated IL-33 in Pericytes and Stromal Cells Promotes Metastasis Through Tumour-Associated Macrophages. Nat Commun (2016) 7(1):11385. doi: 10.1038/ncomms11385
Conflict of Interest: The authors declare that the research was conducted in the absence of any commercial or financial relationships that could be construed as a potential conflict of interest.

Copyright $\odot 2021$ Burganova, Bridges, Thorn and Landsman. This is an open-access article distributed under the terms of the Creative Commons Attribution License (CC BY). The use, distribution or reproduction in other forums is permitted, provided the original author(s) and the copyright owner(s) are credited and that the original publication in this journal is cited, in accordance with accepted academic practice. No use, distribution or reproduction is permitted which does not comply with these terms. 